\title{
HTLV-1-Associated Myelopathy/Tropical Spastic Paraparesis Is Not Associated with SNP rs12979860 of the IL-28B Gene
}

\author{
Antonio C. R. Vallinoto, ${ }^{1}$ Bárbara Brasil Santana, ${ }^{1}$ Keyla S. G. Sá, ${ }^{1}$ \\ Tuane C. S. Ferreira, ${ }^{1}$ Rita Catarina M. Sousa, ${ }^{2}$ Vânia N. Azevedo, ${ }^{1}$ Rosimar N. M. Feitosa, ${ }^{1}$ \\ Luiz Fernando A. Machado, ${ }^{1}$ Marluísa O. G. Ishak, ${ }^{1}$ and Ricardo Ishak ${ }^{1}$ \\ ${ }^{1}$ Laboratório de Virologia, Instituto de Ciências Biológicas, Universidade Federal do Pará, Guamá, 66075-110 Belém, PA, Brazil \\ ${ }^{2}$ Núcleo de Medicina Tropical, Universidade Federal do Pará, Guamá, 66050-240 Belém, PA, Brazil \\ Correspondence should be addressed to Antonio C. R. Vallinoto; vallinoto@ufpa.br
}

Received 2 July 2015; Accepted 13 September 2015

Academic Editor: Mukesh Kumar

Copyright (C) 2015 Antonio C. R. Vallinoto et al. This is an open access article distributed under the Creative Commons Attribution License, which permits unrestricted use, distribution, and reproduction in any medium, provided the original work is properly cited.

\begin{abstract}
The present study investigated the association between the rs12979860 polymorphism in the IL-28B gene and HTLV-1 infection as well as the development of HTLV-1-associated myelopathy/tropical spastic paraparesis (HAM/TSP). HTLV-1-infected patients (26 HAM/TSP symptomatic and 53 asymptomatic) and 300 seronegative healthy controls were investigated. Plasma levels of the cytokines TNF- $\alpha$, TNF- $\beta$, IL-8, IL-10, IL-6, and IFN- $\gamma$ from infected patients were measured using an indirect enzyme-linked immunosorbent assay. The HTLV proviral load was measured using a real-time PCR assay, and T-cell subset counts were determined by flow cytometry. Real-time PCR was used to genotype the rs12979860 SNP. The allelic and genotypic distributions displayed no significant differences among the investigated groups. No significant association between the serum cytokine levels and the presence of the rs12979860 SNP in symptomatic and asymptomatic subjects was observed. A positive correlation $(p=0.0015)$ between TNF$\beta$ and IFN- $\gamma$ was observed in the asymptomatic group, but a positive correlation was only observed $(p=0.0180)$ between TNF- $\alpha$ and IL-6 in the HAM/TSP group. The proviral load was significantly higher in HAM/TSP patients than in asymptomatic subjects. The present results do not support a previous report indicating an association between the SNP rs12979860 and HAM/TSP outcome.
\end{abstract}

\section{Introduction}

Human T-cell lymphotropic virus 1 (HTLV-1) is a member of the Retroviridae family and Deltaretrovirus genus [1]. HTLV1 infection occurs worldwide and affects approximately 15 to 20 million individuals on all continents [2-4].

Most individuals infected with HTLV-1 remain asymptomatic for life, but 5-10\% develop clinical symptoms $[5,6]$. HTLV-1-associated myelopathy/tropical spastic paraparesis (HAM/TSP) and adult T-cell leukemia/lymphoma (ATLL) are the primary clinical manifestations affecting HTLV-1infected subjects $[1,7]$.

Although recent studies indicate the possible use of genetic biomarkers as predictive factors associated with the outcome of the clinical manifestations [8-10], the involvement of these markers had remained unknown until now.
Furthermore, HAM/TSP pathogenesis involves an immunemediated response characterized by inflammatory mechanisms, which lead to the chronic destruction of myelin in the central nervous system $[7,11]$.

Interleukin-28B (IL-28B) is a member of a recently characterized family of cytokines known as interferon $\lambda$ (IFN- $\lambda 1$, IFN- $\lambda 2$, and IFN- $\lambda 3$ or interleukin-29, interleukin$28 \mathrm{~A}$, and interleukin-28B, resp.) [12]. IFN- $\lambda$ is induced by the same stimulus that induces IFN- $\alpha / \beta[13,14]$, and studies have revealed that IFN- $\lambda$ inhibits viral replication $[15,16]$.

During a viral infection, Toll-like receptor-3, Toll-like receptor-4, and Toll-like receptor-7 recognize dsRNA and ssRNA in the cytoplasm or endosomes, activating RIG$1, \mathrm{NF} \kappa \mathrm{B}, \mathrm{IRF} 3$, and IRF7 which stimulate the expression of the $I L-28 B$ gene [17-21]. When secreted, IL-28B binds 
their receptors and activates JAK-STAT-1/2 signaling pathways promoting transcription of interferon-stimulated genes (ISGs) that can result in expression of protein kinase RNAactivated (PKR), O-acetyl-L-serine (OAS), and proinflammatory cytokines $[12,22,23]$. Recently, Treviño et al. [24] reported an association between IL-28B polymorphisms and HAM/TSP outcome in Spanish patients, but those results were contested by Sanabani et al. [25] in a southeastern Brazilian population.

Regarding these controversial results, the present study investigated whether the rs 12979860 polymorphism in the IL$28 \mathrm{~B}$ gene is associated with HTLV-1 infection and the progression to HAM/TSP in patients from the Amazon region of Brazil, a population ethnically different from the previously studied Spanish and southeastern Brazilian populations.

\section{Material and Methods}

2.1. Populations Studied. The study group included $79 \mathrm{HTLV}-$ 1-infected subjects (26 HAM/TSP symptomatic and 53 asymptomatic) attending the outpatient clinic of the Tropical Medicine Nucleus of the Federal University of Pará and 300 seronegative healthy controls from the Virus Laboratory. To avoid confounding factors associated with ethnic origin, which eventually could cause sample bias and influence the genotypic and allelic frequencies, both groups were composed of subjects residing in Belém and had the same ethnic origin. All individuals were recruited between May 2005 and January 2012 and signed an informed consent form.

2.2. Obtaining Samples. Blood samples were collected in Vacutainer tubes containing K3-EDTA (Becton \& Dickinson, Cambridge, UK) as an anticoagulant to obtain plasma and peripheral blood mononuclear cells (PBMCs). The samples were directed to the Virus Laboratory of the Biological Sciences Institute of the Federal University of Pará and stored at $-20^{\circ} \mathrm{C}$ before use. The samples were previously screened for anti-HTLV using an enzyme-linked immunosorbent assay (Ortho Diagnostic Systems Inc., USA), and infection was confirmed by nested PCR as previously described [26]. The clinical diagnosis of HAM/TSP followed the criteria previously described [27].

2.3. Cytokine Levels. The plasma levels of cytokines TNF$\alpha$, TNF- $\beta$, IL-8, IL-10, IL-6, and IFN- $\gamma$ from patients were evaluated by indirect enzyme-linked immunosorbent assays (Human ELISA Ready-SET-Go, EBioscience, Inc., San Diego, CA).

2.4. LTCD $^{+} /$LTCD $^{+}$Count and Proviral Load Levels. The HTLV-1 proviral load and CD $4^{+} \mathrm{T}$ lymphocyte counts in HTLV-1-infected individuals were assessed at the time of entry into the study. Blood samples were processed within 4 hours of collection, and T-cell subset counts were determined by flow cytometry (FACScount, Becton \& Dickinson, USA) using the FACScount reagent immunomonitoring kit according to a standard protocol recommended by the manufacturer (Becton \& Dickinson, USA). The quantification of the HTLV proviral load was performed using a real-time PCR assay as previously described [28].

2.5. IL-28B Polymorphism. Real-time PCR (qPCR) was used to genotype the single nucleotide polymorphism (SNP) rs12979860 using the TaqMan Gene Expression Assay AHCS19G kit (Applied Biosystems, Foster City, CA, USA) following the technical procedures recommended by the manufacturer. A custom-designed assay provided by Applied Biosystems was used. The following primer sequences were used in these assays: forward primer, $5^{\prime}$-GCCTGTCGTGTACTGAACCA-3'; reverse primer, $5^{\prime}$-GCGCGGAGTGCAATTCAAC- $3^{\prime}$; and the probes (VIC) $-5^{\prime}$-TGGTTCGCGCCTTC- $3^{\prime}$ and (FAM) $-5^{\prime}$-CTGGTTCACGCCTTC- $3^{\prime}$ for the C and $\mathrm{T}$ alleles, respectively.

The PCR reactions were prepared using TaqMan Universal PCR Master Mix components (Applied Biosystems, Foster City, CA, USA), which consisted of nucleotides, buffer, UNG, AmpliTaq, and a passive reference dye (ROX). The reaction mixture contained 5.0 $\mu \mathrm{L}$ of Master Mix, $3.5 \mu \mathrm{L}$ of $\mathrm{H}_{2} \mathrm{O}, 0.5 \mu \mathrm{L}$ of IL-28B assay components (primer set and probe), and $1.0 \mu \mathrm{L}$ of DNA from each sample. The final volume for each reaction was $10 \mu \mathrm{L}$.

The Step One Plus Real-Time PCR System (Applied Biosystems, Foster City, CA, USA) was used to perform the qPCR experiments with the following cycling protocol: one cycle of $60^{\circ} \mathrm{C}$ for 2 minutes, one cycle of $95^{\circ} \mathrm{C}$ for 10 minutes, and 50 cycles of $95^{\circ} \mathrm{C}$ for 15 seconds and $60^{\circ} \mathrm{C}$ for 20 seconds.

The program StepOne v2.2 (Applied Biosystems, Foster City, CA, USA) was employed to interpret the reaction results using the graphical representation of VIC and FAM fluorophore emissions with respect to constitutive ROX emissions.

2.6. Statistical Analysis. The genotypic and allelic frequencies observed were obtained by direct counting, and comparisons between frequencies were calculated using the Chi-square test. The association analysis between the genotype frequencies and the arithmetic average of the values of proviral load, cytokines, and TCD $4^{+}$and $\mathrm{TCD} 8^{+}$lymphocyte counts were performed using the Mann-Whitney test. Pearson's linear correlation analysis was used to compare the cytokine levels. Hardy-Weinberg equilibrium was calculated using the software BioEstat 5.0 [29]. A $p$ value $<0.05$ was considered statistically significant.

\section{Results}

3.1. Allelic and Genotypic Frequencies. The allele and genotype distributions displayed no significant differences between HTLV-infected subjects and healthy controls as well as between HAM/TSP and asymptomatic patients (Table 1). The CT genotype was the most prevalent among the groups analyzed, ranging from 44.3 to $50 \%$, and the same predominance was observed for allele $\mathrm{C}$, which displayed frequencies ranging from 51.67 to $52.83 \%$. Hardy-Weinberg equilibrium was observed in both groups. Furthermore, the odds ratio analysis demonstrated that the SNP rs12979860 was not 
TABLE 1: Genotypic and allelic frequencies of the SNP rs12979860 in HTLV-1-infected patients and healthy control subjects.

\begin{tabular}{|c|c|c|c|c|c|c|c|c|}
\hline SNP rs12979860 $(\mathrm{C}>\mathrm{T})$ & $\begin{array}{l}\text { HTLV patients } \\
\begin{array}{c}(n=79) \\
n(\%)\end{array}\end{array}$ & $\begin{array}{l}\text { Control group } \\
\begin{array}{c}(n=300) \\
n(\%)\end{array}\end{array}$ & OR & $p$ & $\begin{array}{c}\text { TSP/HAM } \\
(n=26) \\
n(\%)\end{array}$ & $\begin{array}{c}\text { Asymptomatic } \\
\begin{array}{c}(n=53) \\
n(\%)\end{array}\end{array}$ & OR & $p$ \\
\hline \multicolumn{9}{|l|}{ Genotype } \\
\hline $\mathrm{CC}$ & $24(30.38)$ & $80(26.67)$ & 1.2000 & 0.6056 & $09(34.61)$ & $15(28.30)$ & 1.3412 & 0.7543 \\
\hline CT & $35(44.30)$ & $150(50.00)$ & 0.7955 & 0.4385 & $09(34.61)$ & $26(49.06)$ & 0.5498 & 0.3305 \\
\hline TT & $20(25.32)$ & $70(23.33)$ & 1.1138 & 0.8259 & $08(30.77)$ & $12(22.64)$ & 1.5185 & 0.6133 \\
\hline \multicolumn{9}{|l|}{ Allele } \\
\hline $\mathrm{C}$ & $83(52.53)$ & $310(51.67)$ & \multirow{2}{*}{1.0353} & \multirow{2}{*}{0.9171} & $27(51.92)$ & $56(52.83)$ & \multirow{2}{*}{0.9643} & \multirow{2}{*}{0.9504} \\
\hline $\mathrm{T}$ & $75(47.47)$ & $290(48.33)$ & & & $25(48.08)$ & $50(47.17)$ & & \\
\hline
\end{tabular}

OR: odds ratio.
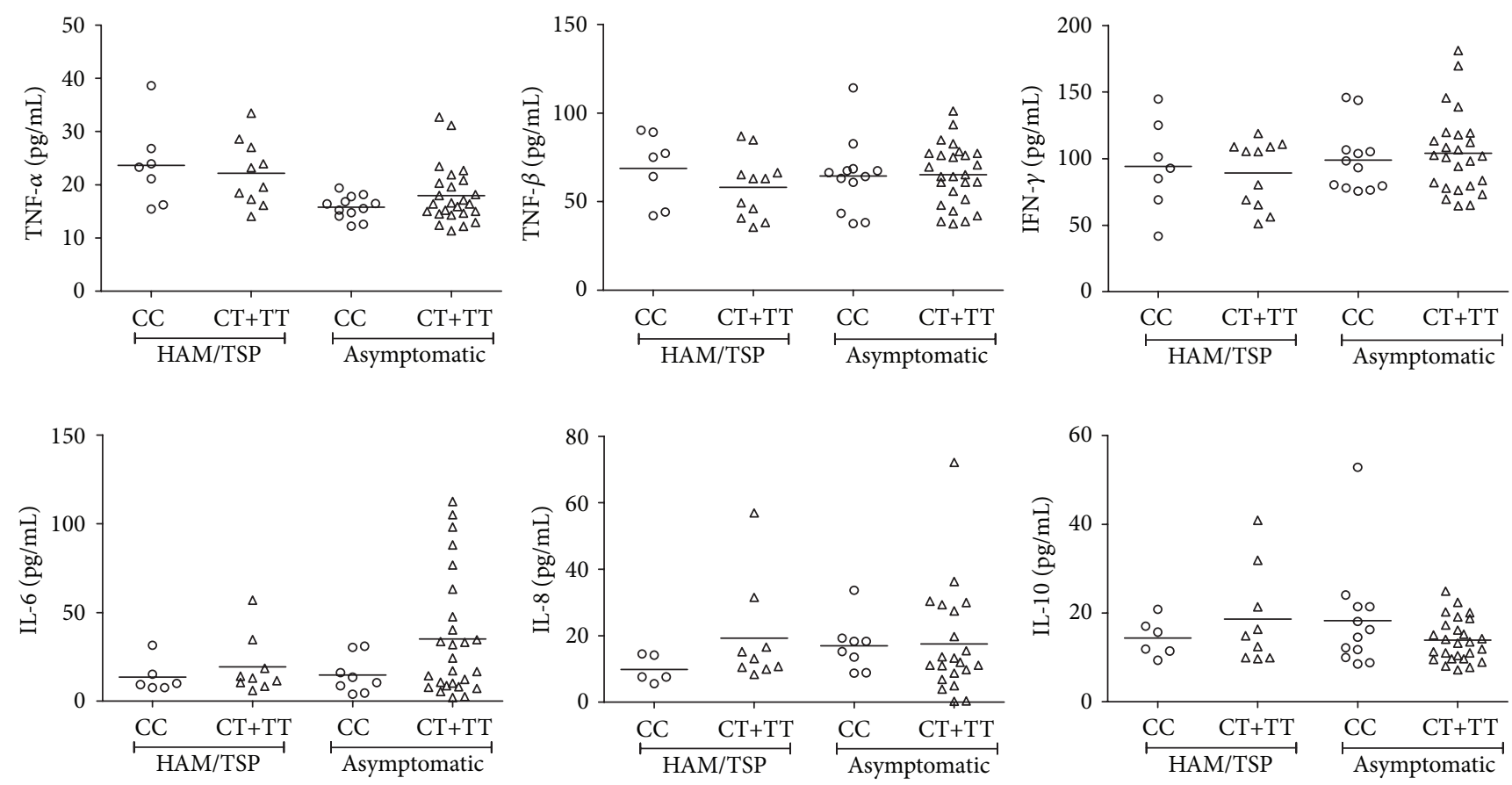

FIGURE 1: Cytokine serum levels according to the presence of the SNP rs12979860 in the HAM/TSP and asymptomatic groups.

related to susceptibility or resistance to HTLV-1 infection or to the clinical prognosis of the infection.

3.2. Cytokine Levels. No significant association (Figure 1) was observed between cytokine levels and the presence of rs12979860 (genotypes CT+TT). However, when the cytokine levels were measured according to the presence or absence of HAM/TSP symptoms (Figure 2), a significantly increased level of TNF- $\alpha$ was observed in the HAM/TSP patients. In an attempt to correlate each cytokine value with each other (Figure 2), a positive correlation $\left(p=0.0013 ; r^{2}=0.3965\right)$ between TNF- $\beta$ and IFN- $\gamma$ was observed in the asymptomatic group, whereas TNF- $\alpha$ and IL-6 $\left(p=0.0162 ; r^{2}=\right.$ $0.3944)$ as well as IL-10 and IL-8 $\left(p=0.0207 ; r^{2}=0.3476\right)$ displayed positive correlations in the HAM/TSP group.
3.3. Proviral Load and $C D 4^{+} / C D 8^{+}$T-Cells Levels. The proviral load was significantly increased in HAM/TSP patients compared with asymptomatic subjects $(p=0.0002$; Figure 3), but no association with the presence of the rs12979860 polymorphism was observed (Figure 4). No association was observed between the $\mathrm{CD} 4^{+}$and $\mathrm{CD}^{+} \mathrm{T}$ lymphocyte levels and symptomatic and asymptomatic infected subjects or the presence or absence of the SNP rs12979860.

\section{Discussion}

Symptomatic HTLV infection has been described in 5-10\% of infected individuals [5], who may manifest mainly ATLL and HAM/TSP as the two most serious diseases associated with HTLV infection $[1,7,30]$. Several studies have attempted to associate the presence of SNPs in the host's genome with 

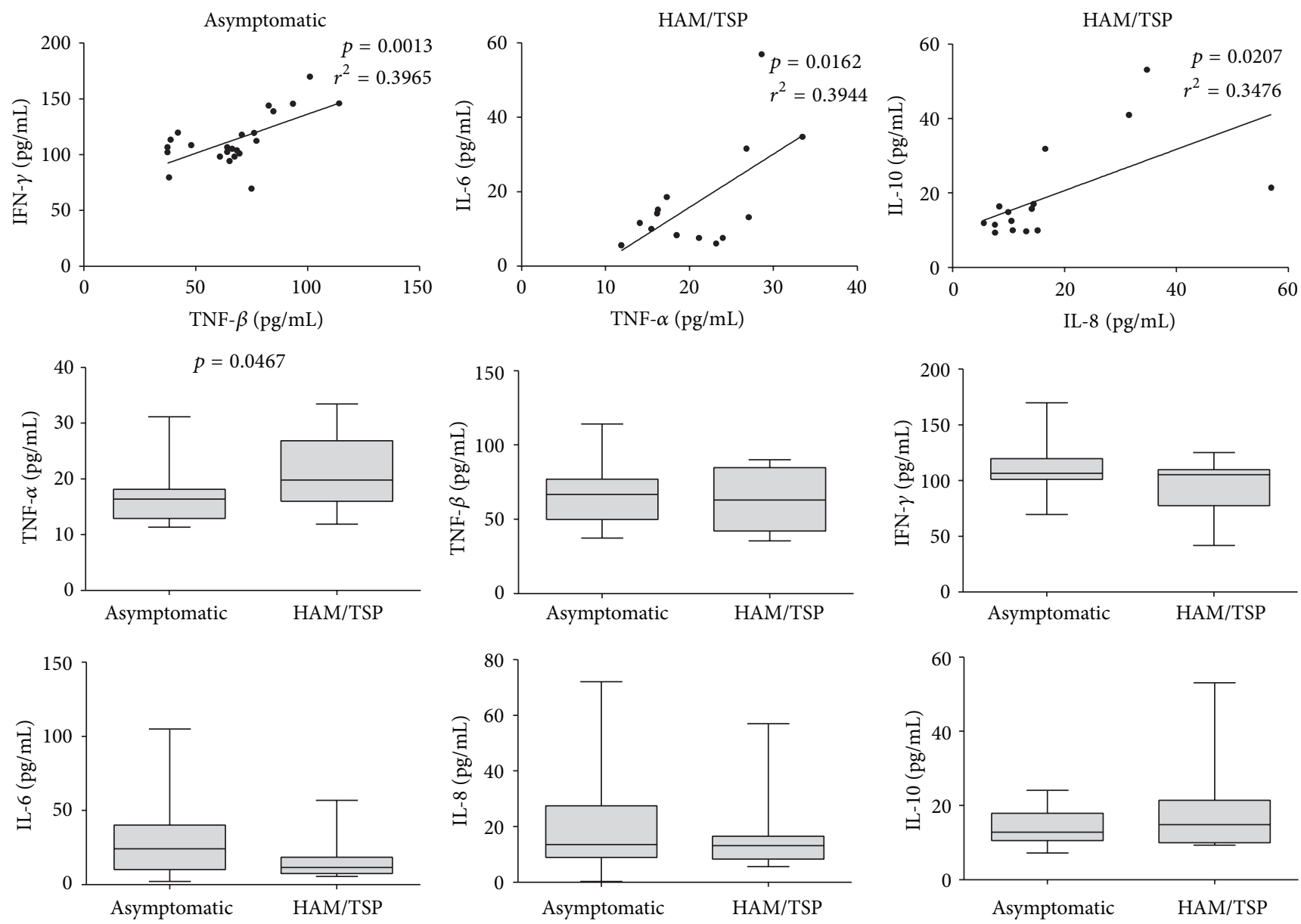

FIGURE 2: Comparison and correlation of the cytokine serum levels in the HAM/TSP and asymptomatic groups.
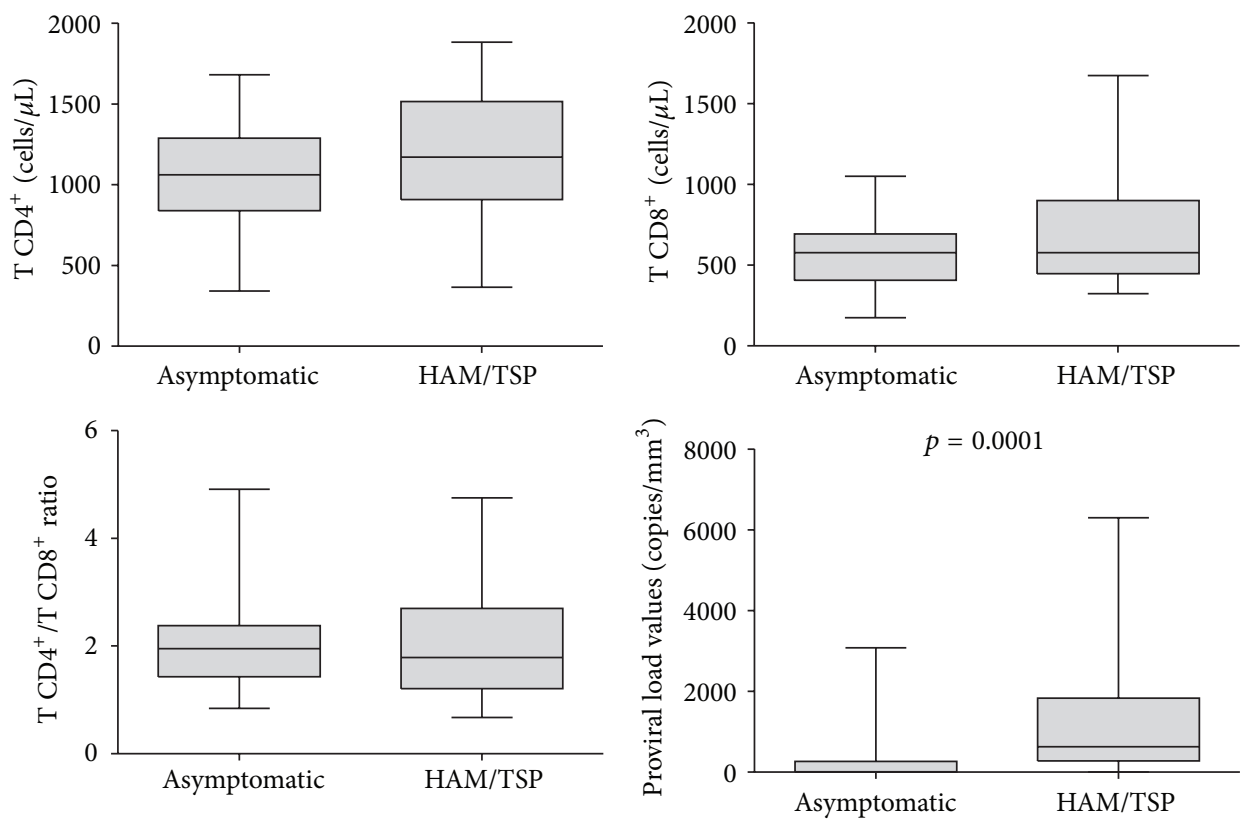

FIgURE 3: $\mathrm{CD}^{+} / \mathrm{CD}^{+}$T-cell and proviral load measurements in the HAM/TSP and asymptomatic groups. 

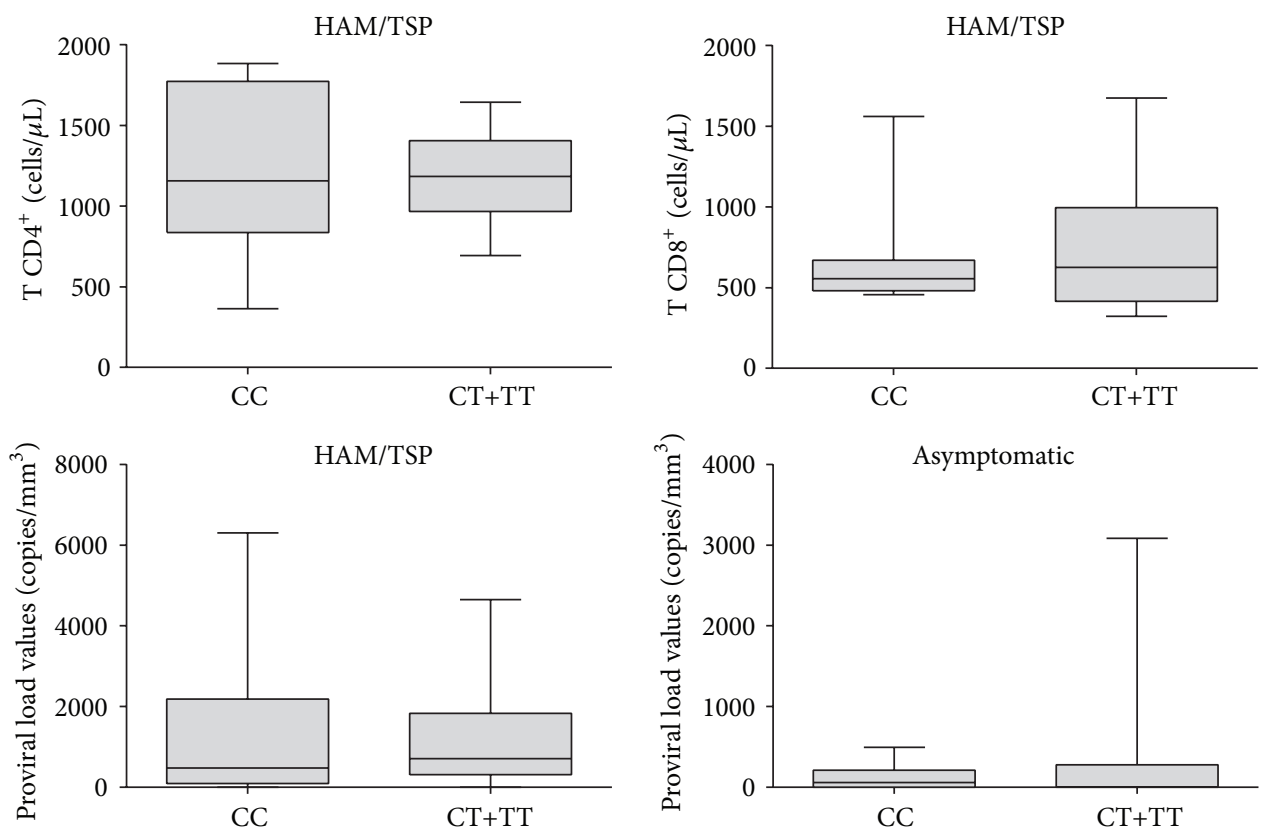

FIGURE 4: $\mathrm{CD}^{+} / \mathrm{CD}^{+}$T-cell and proviral load measurements in the HAM/TSP and asymptomatic groups according to the presence of the SNP rs12979860.

susceptibility to infection or the outcome of clinical manifestations in infected subjects [8-10, 31]. Recently, Treviño et al. [24] investigated the prevalence of the rs12979860 polymorphism in the IL-28B gene in a Spanish group and reported an increased frequency of the CT/TT genotypes in HAM/TSP patients compared with asymptomatic subjects. Furthermore, these authors reported a greater median proviral load in carriers of the CT/TT genotypes, suggesting the influence of this genetic background as an important biomarker for follow-up in the HTLV-infected individuals.

The results presented herein do not agree with this hypothesis given that we did not observe any differences in the allelic and genotypic frequencies among the symptomatic patients, asymptomatic patients, and control individuals. Furthermore, according to our results, the studied SNP had no influence on the HTLV proviral load, confirming the data previously obtained in a southern Brazilian population [25]; thus, our results do not support the use of this SNP as a predictive factor in the development of HAM/TSP. A possible explanation for the lack of agreement is the existence of distinct ethnic differences between the Brazilian and Spanish populations examined. The significantly increased levels of the HTLV-1 proviral load in HAM/TSP patients compared with asymptomatic subjects are a typical finding that has been commonly used as a biomarker for HAM/TSP prognosis [32].

The pathogenesis of HAM/TSP is based on the host's immunological response against infected cells, and cytokines play a central role in the regulation of the $\mathrm{CD} 8^{+}$T lymphocyte response against HTLV-1 to control virus replication and HTLV-infected cell proliferation [6,33]. According to our results, no association was observed between the IL-28B genotypes and cytokine plasma levels; however, significantly increased serum levels of TNF- $\alpha$ were observed in the HAM/TSP group compared with the controls. Furthermore, a positive correlation between TNF- $\beta$ and IFN- $\gamma$ was evident in the asymptomatic group. These results may reflect the systemic antiviral cellular response against $\mathrm{CD} 4^{+} \mathrm{T}$ cells infected with HTLV-1. Positive correlations between TNF- $\alpha$ and IL6 as well as IL-10 and IL- 8 were observed in the HAM/TSP group, and these results are a potential consequence of the proinflammatory immune responses typically observed in this group of patients. Lal and Rudolph [34] reported increased IL- 6 and TNF- $\alpha$ levels in culture supernatants from HTLV-1/HTLV-2-infected individuals compared with normal controls, suggesting that these cytokines may regulate lymphocyte proliferation in infected individuals. The in vivo results of Starling et al. [32] demonstrate increased serum concentrations of IL- 6 and TNF- $\alpha$ in HAM/TSP patients compared with asymptomatic subjects.

\section{Conclusion}

Knowledge regarding the immunogenetic and virological profile of HTLV-infected subjects can guide patient clinical counseling, but our results did not reveal any association between the SNP rs12979860 and the TSP/HAM outcome, refuting previous evidence. However, populationscale genetic studies involving larger samples and different ethnic groups are recommended to confirm these results.

\section{Conflict of Interests}

The authors declare no conflict of interests.

\section{Authors' Contribution}

Antonio C. R. Vallinoto and Bárbara Brasil Santana made equal contributions to the present study. 


\section{Acknowledgments}

This work was partially supported by grants from the Brazilian National Council for Scientific and Technological Development (CNPq [302540/2010-5]), the Office of the Dean of Research and Graduate Studies (Pró-Reitoria de Pesquisa e Pós-Graduação da UFPA (PROPESP/UFPA) [23073013354/2014-70]), and the Research Support and Development Foundation (Fundação de Apoio e Desenvolvimento da Pesquisa (FADESP)). The authors thank all the subjects who participated in the present study.

\section{References}

[1] B. J. Poiesz, F. W. Ruscetti, A. F. Gazdar, P. A. Bunn, J. D. Minna, and R. C. Gallo, "Detection and isolation of type C retrovirus particles from fresh and cultured lymphocytes of a patient with cutaneous T-cell lymphoma," Proceedings of the National Academy of Sciences of the United States of America, vol. 77, no. 12, pp. 7415-7419, 1980.

[2] A. Gessain and O. Cassar, "Epidemiological aspects and world distribution of HTLV-1 infection," Frontiers in Microbiology, vol. 3, article 388, 2012.

[3] A. Gessain and G. de Thé, "Geographic and molecular epidemiology of primate T lymphotropic retroviruses: HTLV-I, HTLVII, STLV-I, STLV-PP, and PTLV-L," Advances in Virus Research, vol. 47, pp. 377-426, 1996.

[4] F. A. Proietti, A. B. F. Carneiro-Proietti, B. C. Catalan-Soares, and E. L. Murphy, "Global epidemiology of HTLV-I infection and associated diseases," Oncogene, vol. 24, no. 39, pp. 60586068, 2005.

[5] W. A. Blattner, D. W. Blayney, M. Robert-Guroff et al., "Epidemiology of human T-cell leukemia/lymphoma virus," Journal of Infectious Diseases, vol. 147, no. 3, pp. 406-416, 1983.

[6] C. R. M. Bangham, “The immune response to HTLV-I," Current Opinion in Immunology, vol. 12, no. 4, pp. 397-402, 2000.

[7] M. Osame, K. Usuku, S. Izumo et al., "HTLV-I associated myelopathy, a new clinical entity," The Lancet, vol. 327, no. 8488, pp. 1031-1032, 1986.

[8] M. Taghaddosi, S. A. R. Rezaee, H. Rafatpanah, T. Rajaei, R. F. Hosseini, and V. Narges, "Association between HLA class I alleles and proviral load in HTLV-I associated myelopathy/tropical spastic paraperesis (HAM/TSP) patients in Iranian population," Iranian Journal of Basic Medical Sciences, vol. 16, no. 3, pp. 264267, 2013.

[9] A. Treviño, J. L. Vicario, M. Lopez et al., "Association between HLA alleles and HAM/TSP in individuals infected with HTLV1," Journal of Neurology, vol. 260, no. 10, pp. 2551-2555, 2013.

[10] A. C. R. Vallinoto, B. B. Santana, E. L. dos Santos et al., "FAS$670 \mathrm{~A} / \mathrm{G}$ single nucleotide polymorphism may be associated with human $\mathrm{T}$ lymphotropic virus-1 infection and clinical evolution to TSP/HAM," Virus Research, vol. 163, no. 1, pp. 178182, 2012.

[11] M. Saito and C. R. M. Bangham, "Immunopathogenesis of human T-cell leukemia virus type-1-associated myelopathy/tropical spastic paraparesis: recent perspectives," Leukemia Research and Treatment, vol. 2012, Article ID 259045, 12 pages, 2012.

[12] P. Sheppard, W. Kindsvogel, W. Xu et al., "IL-28, IL-29 and their class II cytokine receptor IL-28R," Nature Immunology, vol. 4, no. 1, pp. 63-68, 2003.
[13] M. D. Robek, B. S. Boyd, and F. V. Chisari, "Lambda interferon inhibits hepatitis B and C virus replication," Journal of Virology, vol. 79, no. 6, pp. 3851-3854, 2005.

[14] M. Mordstein, G. Kochs, L. Dumoutier et al., "Interferon- $\lambda$ contributes to innate immunity of mice against influenza A virus but not against hepatotropic viruses," PLoS Pathogens, vol. 4, no. 9, Article ID e1000151, 2008.

[15] N. Ank, M. B. Iversen, C. Bartholdy et al., "An important role for type III interferon (IFN- $\lambda$ /IL-28) in TLR-induced antiviral activity," The Journal of Immunology, vol. 180, no. 4, pp. 24742485, 2008.

[16] S. Kamihira, T. Usui, T. Ichikawa et al., "Paradoxical expression of IL-28B mRNA in peripheral blood in human T-cell leukemia virus Type-1 mono-infection and co-infection with hepatitis $\mathrm{C}$ virus," Virology Journal, vol. 9, article 40, 2012.

[17] E. M. Coccia, M. Severa, E. Giacomini et al., "Viral infection and Toll-like receptor agonists induce a differential expression of type I and $\lambda$ interferons in human plasmacytoid and monocytederived dendritic cells," European Journal of Immunology, vol. 34, no. 3, pp. 796-805, 2004.

[18] M. B. Iversen and S. R. Paludan, "Mechanisms of type III interferon expression," Journal of Interferon and Cytokine Research, vol. 30, no. 8, pp. 573-578, 2010.

[19] H.-C. Lee, S. Narayanan, S.-J. Park, S.-Y. Seong, and Y. S. Hahn, "Transcriptional regulation of IFN- $\lambda$ genes in hepatitis C virus-infected hepatocytes via IRF-3.IRF-7·NF- $\kappa$ B complex," The Journal of Biological Chemistry, vol. 289, no. 8, pp. 5310-5319, 2014.

[20] K. Onoguchi, M. Yoneyama, A. Takemura et al., "Viral infections activate types I and III interferon genes through a common mechanism," The Journal of Biological Chemistry, vol. 282, no. 10, pp. 7576-7581, 2007.

[21] J. Sirén, J. Pirhonen, I. Julkunen, and S. Matikainen, "IFN- $\alpha$ regulates TLR-dependent gene expression of IFN- $\alpha$, IFN- $\beta$, IL28, and IL-29," Journal of Immunology, vol. 174, no. 4, pp. 19321937, 2005.

[22] N. Ank, H. West, C. Bartholdy, K. Eriksson, A. R. Thomsen, and S. R. Paludan, "Lambda interferon (IFN- $\lambda$ ), a type III IFN, is induced by viruses and IFNs and displays potent antiviral activity against select virus infections in vivo," Journal of Virology, vol. 80, no. 9, pp. 4501-4509, 2006.

[23] S. V. Kotenko, G. Gallagher, V. V. Baurin et al., "IFN-lambdas mediate antiviral protection through a distinct class II cytokine receptor complex," Nature Immunology, vol. 4, no. 1, pp. 69-77, 2003.

[24] A. Treviño, M. Lopez, E. Vispo et al., "Development of tropical spastic paraparesis in human T-lymphotropic virus type 1 carriers is influenced by interleukin 28B gene polymorphisms," Clinical Infectious Diseases, vol. 55, no. 1, pp. el-e4, 2012.

[25] S. S. Sanabani, Y. Nukui, J. Pereira et al., "Lack of evidence to support the association of a single IL28B genotype SNP rs12979860 with the HTLV-1 clinical outcomes and proviral load," BMC Infectious Diseases, vol. 12, article 374, 2012.

[26] A. C. R. Vallinoto, M. O. G. Ishak, V. N. Azevedo et al., "Molecular epidemiology of human T-lymphotropic virus type II infection in Amerindian and urban populations of the Amazon region of Brazil," Human Biology, vol. 74, no. 5, pp. 633-644, 2002.

[27] C. M. De Castro-Costa, A. Q. C. Araújo, M. M. Barreto et al., "Proposal for diagnostic criteria of tropical spastic paraparesis/HTLV-I- associated myelopathy (TSP/HAM)," AIDS 
Research and Human Retroviruses, vol. 22, no. 10, pp. 931-935, 2006.

[28] B. P. Tamegão-Lopes, P. R. Rezende, L. M. C. Maradei-Pereira, and J. A. R. De Lemos, "HTLV-1 and HTLV-2 proviral load: a simple method using quantitative real-time PCR," Revista da Sociedade Brasileira de Medicina Tropical, vol. 39, no. 6, pp. 548552, 2006.

[29] M. Ayres, J. R. Ayres, D. L. M. Ayres, and A. S. Santos, BIOSTAT 5.0: Aplicações Estatísticas nas Áreas das Ciências Biológicas e Médicas, Sociedade Civil Mamirauá/MCT-CNPq/Conservation International, Belém, Brazil, 2007.

[30] S. Ahmadi Ghezeldasht, A. Shirdel, M. A. Assarehzadegan et al., "Human T lymphotropic virus type I (HTLV-I) oncogenesis: molecular aspects of virus and host interactions in pathogenesis of adult T cell leukemia/lymphoma (ATL)," Iranian Journal of Basic Medical Sciences, vol. 16, no. 3, pp. 179-195, 2013.

[31] G. S. Pontes, B. Tamegão-Lopes, L. F. A. Machado et al., "Characterization of mannose-binding lectin gene polymorphism among human T-cell lymphotropic virus 1 and 2-infected asymptomatic subjects," Human Immunology, vol. 66, no. 8, pp. 892-896, 2005.

[32] A. L. B. Starling, O. A. Martins-Filho, J. R. Lambertucci et al., "Proviral load and the balance of serum cytocines in HTLV1-asymptomatic infection and in HTLV-1-associated myelopathy/tropical spastic paraparesis (HAM/TSP)," Acta Tropica, vol. 125, no. 1, pp. 75-81, 2013.

[33] C. R. M. Bangham and M. Osame, "Cellular immune response to HTLV-1,” Oncogene, vol. 24, no. 39, pp. 6035-6046, 2005.

[34] R. B. Lal and D. L. Rudolph, "Constitutive production of interleukin- 6 and tumor necrosis factor- $\alpha$ from spontaneously proliferating T cells in patients with human T-cell lymphotropic virus type-I/II," Blood, vol. 78, no. 3, pp. 571-574, 1991. 


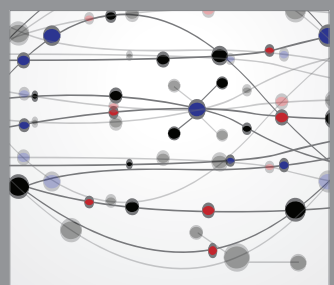

The Scientific World Journal
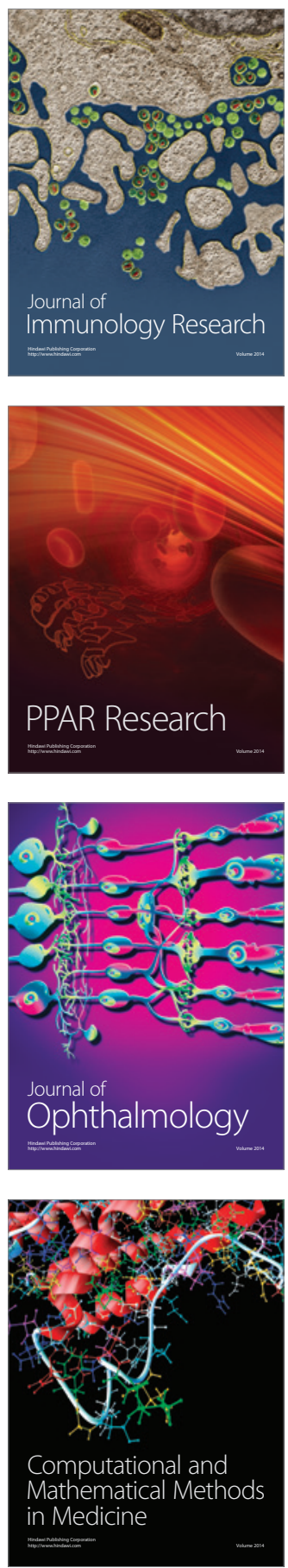

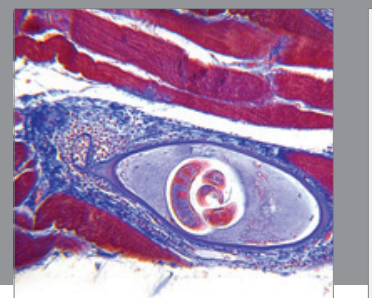

Gastroenterology

Research and Practice
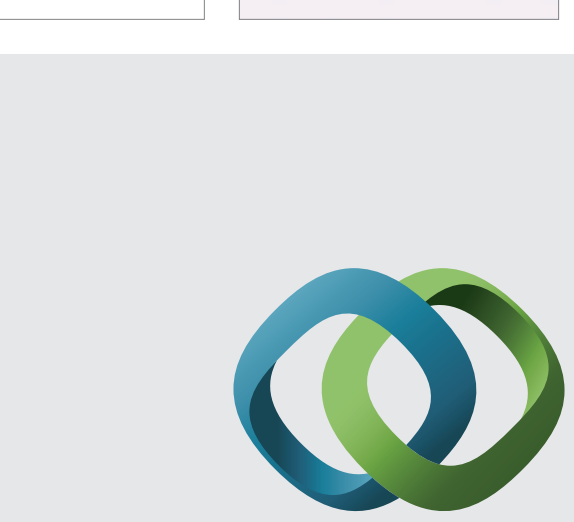

\section{Hindawi}

Submit your manuscripts at

http://www.hindawi.com
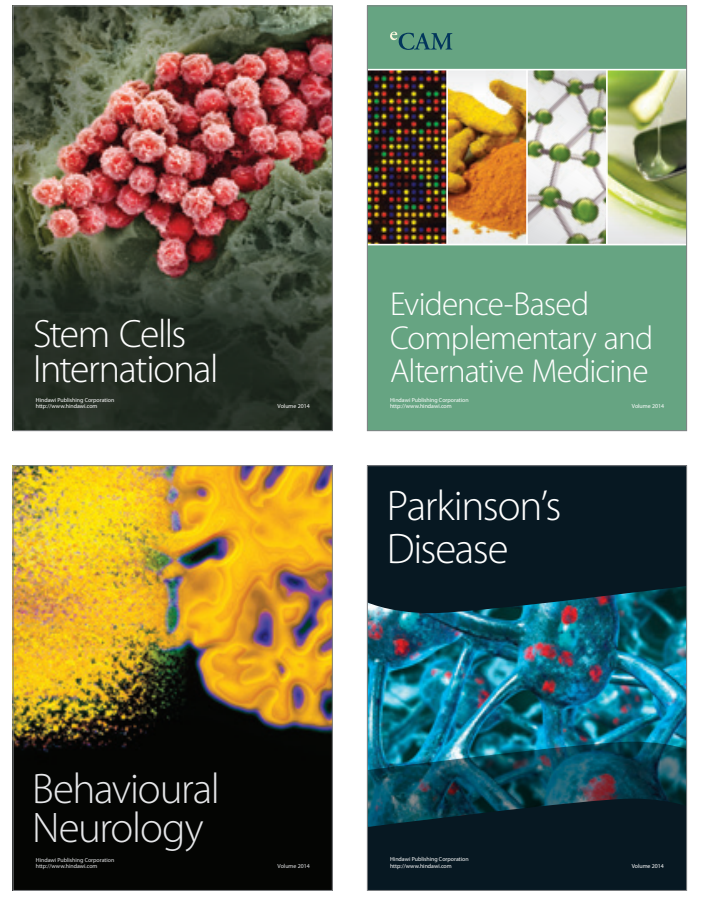
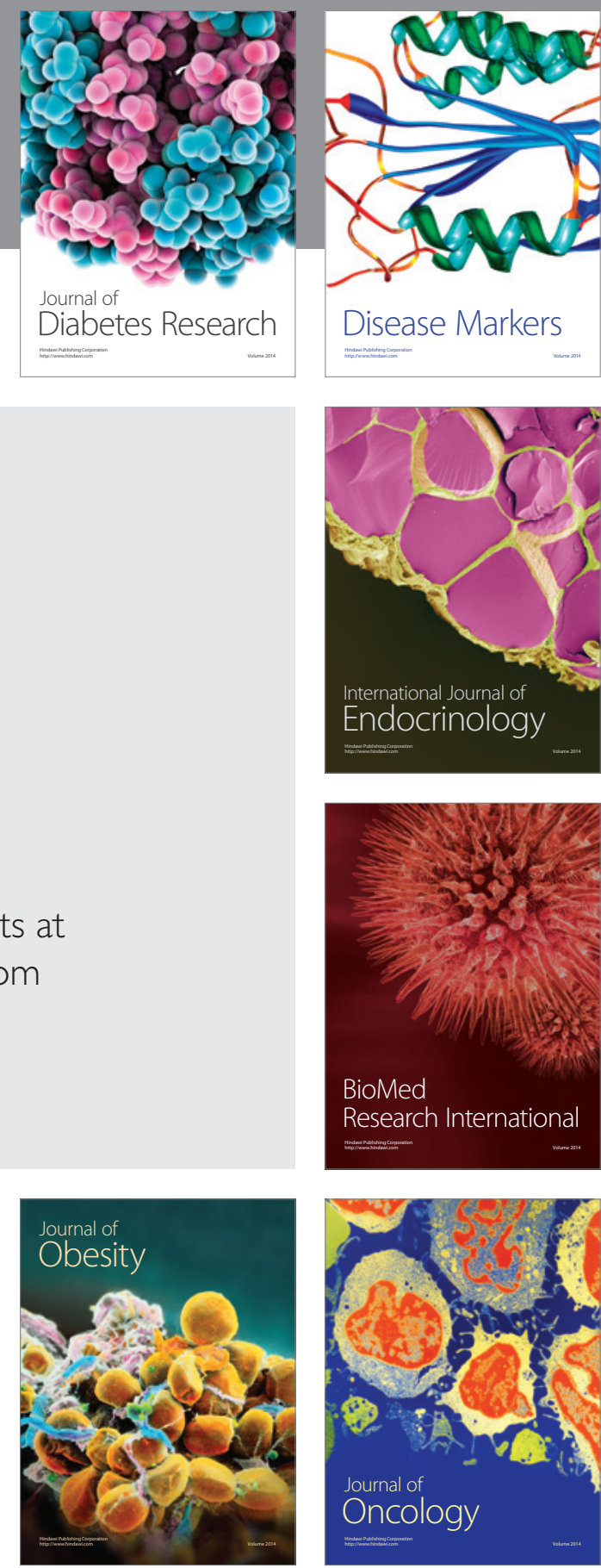

Disease Markers
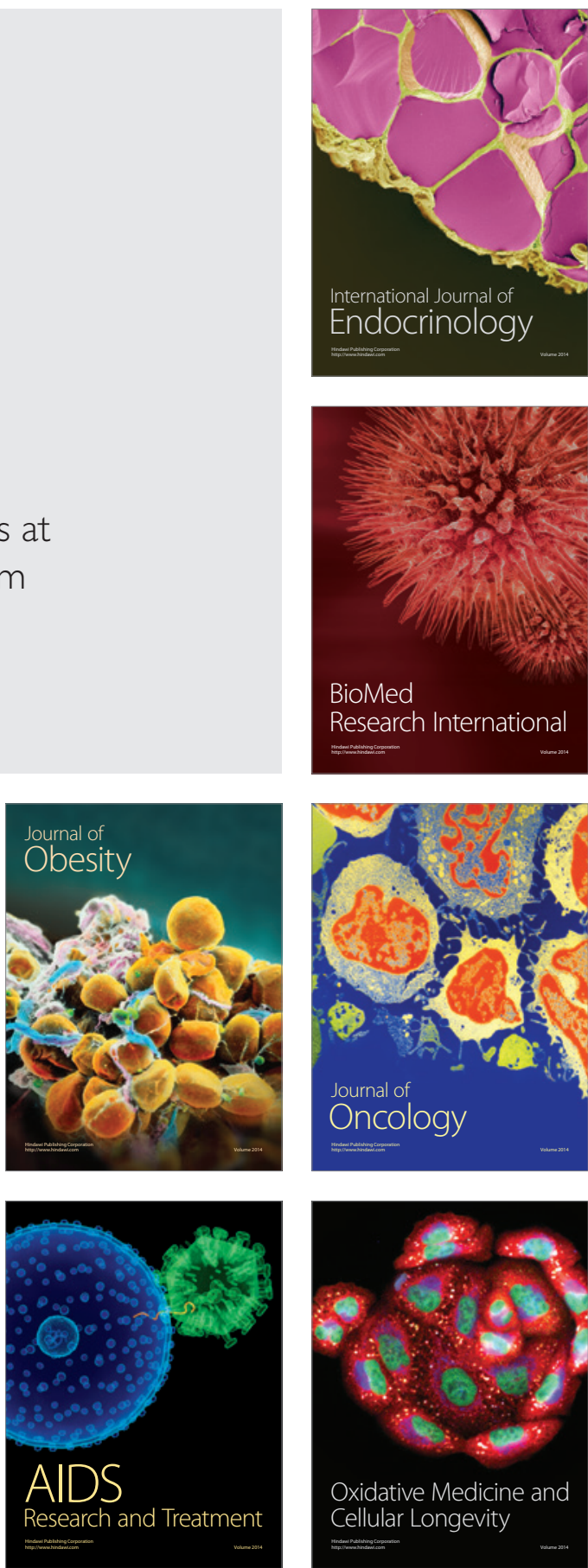